\title{
Youth unemployment in Greece: measuring the challenge
}

\author{
David NF Bell ${ }^{1 *}$ and David G Blanchflower ${ }^{1,2,3}$
}

\author{
* Correspondence: \\ d.n.f.bell@stir.ac.uk \\ ${ }^{1}$ Division of Economics, Stirling \\ Management School, University of \\ Stirling, Stirling, UK \\ Full list of author information is \\ available at the end of the article
}

\begin{abstract}
A historically high level of youth unemployment presents Greece with a huge social and economic challenge. This paper analyses various dimensions of this challenge. We argue that though the conventional definition of "youth" is the 16-24 age group, there is a strong case for considering 25 to 29-year-olds as sharing common problems with conventionally defined youth. There are also grounds for examining why females seem to fare worse than males in the Greek labour market. The negative effects of the recession on Greek well-being have affected all age groups.

JEL codes: J19; J21; J30; J64

Keywords: Unemployment; Youth; Labor market; Well-being; Happiness; Life satisfaction; Great recession
\end{abstract}

\section{Introduction}

Youth unemployment is one of the principal economic and social problems of this decade. It has grown rapidly since the onset of the Great Recession. In a European context, its growth has been concentrated in Southern Europe and particularly in Greece and Spain, where more than half of young people in the labour force are unemployed (Table 1). Of interest, though, is the fact that in some countries like the UK and Sweden, the ratio of youth to adult unemployment rates is close to four, whereas in Greece and Spain it is closer to two. High relative and absolute youth unemployment rates are both likely to be a cause for concern.

At the time of writing, August 2014, the average youth unemployment rate in the European Union was $23.1 \%$ and $23.9 \%$ in the Eurozone. In total, there were 5.13 million people under the age of 25 in Europe who were unemployed. Of these, $16 \%$ were in Spain, 16\% were in the UK, 14\% were in Italy and 12\% were in France. But, while it is associated often with the very high youth unemployment rates, only 3\% $(169,000)$ of Europe's young unemployed are residents in Greece.

Youth unemployment has been the subject of three major NBER studies by Freeman and Wise (1984), Freeman and Holzer (2000) and Blanchflower and Freeman (2004), where major figures in labour economics have given their views on how the youth labour market works and what to do about youth unemployment. The most important finding from these studies is that long spells of unemployment when you are young creates permanent scars rather than temporary blemishes. Bell and Blanchflower (2011a, 2011b) find similar results in the UK in the current recession. Recent work by Kahn (2010)

(C) 2015 Bell and Blanchflower; licensee Springer. This is an Open Access article distributed under the terms of the Creative Commons Attribution License (http://creativecommons.org/licenses/by/4.0), which permits unrestricted use, distribution, and reproduction in any medium, provided the original work is properly credited. 
Table 1 Youth and adult unemployment rates, June 2014

\begin{tabular}{|c|c|c|c|}
\hline & $\begin{array}{c}\text { 25-74 year } \\
\text { Unemployment rate }\end{array}$ & $\begin{array}{c}<25 \text { year } \\
\text { Unemployment rate }\end{array}$ & $\begin{array}{l}\text { Ratio } \\
(2) /(1)\end{array}$ \\
\hline & (1) & (2) & \\
\hline Romania & 5.7 & 24.4 & 4.3 \\
\hline Sweden & 5.7 & 23.9 & 4.2 \\
\hline Italy & 10.5 & 43.7 & 4.2 \\
\hline United Kingdom & 4.6 & 17.9 & 3.9 \\
\hline Belgium & 7.2 & 23.2 & 3.2 \\
\hline Czech Republic & 5.3 & 16.7 & 3.2 \\
\hline Malta & 4.3 & 13.3 & 3.1 \\
\hline Croatia & 13.7 & 41.7 & 3.0 \\
\hline Norway & 2.5 & 7.3 & 2.9 \\
\hline Hungary & 7.1 & 20.5 & 2.9 \\
\hline Poland & 8.2 & 23.6 & 2.9 \\
\hline Finland & 7.2 & 20.2 & 2.8 \\
\hline Estonia & 6.3 & 17.4 & 2.8 \\
\hline Cyprus & 13.2 & 35.4 & 2.7 \\
\hline Portugal & 12.5 & 33.5 & 2.7 \\
\hline United States & 5.0 & 13.3 & 2.7 \\
\hline Slovakia & 12.2 & 32.3 & 2.6 \\
\hline Luxembourg & 5.7 & 14.8 & 2.6 \\
\hline France & 8.9 & 22.4 & 2.5 \\
\hline European Union (28) & 9.0 & 22.0 & 2.4 \\
\hline Slovenia & 9.3 & 22.3 & 2.4 \\
\hline Spain & 22.4 & 53.5 & 2.4 \\
\hline Denmark & 5.5 & 12.6 & 2.3 \\
\hline Iceland & 4.2 & 9.4 & 2.2 \\
\hline Euro area (18) & 10.4 & 23.1 & 2.2 \\
\hline Ireland & 10.7 & 23.2 & 2.2 \\
\hline Bulgaria & 10.9 & 23.2 & 2.1 \\
\hline Turkey & 7.7 & 16.2 & 2.1 \\
\hline Austria & 4.3 & 9.0 & 2.1 \\
\hline Greece & 25.4 & 53.1 & 2.1 \\
\hline Latvia & 10.6 & 19.7 & 1.9 \\
\hline Lithuania & 9.8 & 17.7 & 1.8 \\
\hline Netherlands & 6.1 & 10.5 & 1.7 \\
\hline Germany & 4.8 & 7.8 & 1.6 \\
\hline
\end{tabular}

has shown that the wage impacts of a cohort reaching adulthood when there is a recession are substantial and long-lasting. A number of authors in a series of unpublished studies have recently examined youth unemployment in the countries most impacted by high levels of youth unemployment, including Cholezas (2013) and Tubadji (2012) for Greece, Rocha Sanchez (2012) for Spain and Pastore (2012) for Italy. 
Youth joblessness has been a problem in many countries for several decades. It has been the subject of a wide range of policy interventions. Yet the accumulated wealth of policy experience failed to prevent a rapid rise in youth unemployment during the so-called "Great Recession". The rise was especially marked in Ireland, Portugal, Spain and Greece, and as we show below, in the Great Recession, it has reached unprecedented levels. This raises serious questions about the relevance of past policy lessons to the present predicament of the youth labour market. Should we discount these past lessons, and what can we learn about future policy from recent experience?

Changes in educational participation influence the size of the youth labour market and, therefore, youth unemployment rates. Thus, voluntary or mandatory increases in educational participation could potentially increase the youth unemployment rate without any increase in the number of young people seeking work. On the other hand, increased educational participation might have no effect on the youth unemployment rate. This is because many students, particularly part-timers, actively participate in the labour market. In addition, the youth unemployment rate does not capture those young people who neither participate in the labour market, nor in education. The so-called NEETs (young people not in education, employment or training) are drawn from both the unemployed and the inactive youth.

There are a number of reasons why youth unemployment rates may be higher than adult rates. In the internal labour market, youths will generally have less specific human capital relevant to the particular firm for whom they work and also less general work skills. Even without a formal last-in first-out (LIFO) policy, firms may take the view that the future benefit of further investment in young workers is outweighed by its current costs. Further, liquidity concerns cause firms to seek layoffs among younger workers first, particularly where statutory redundancy payments are seniority weighted, as is the case in most countries.

In the external labour market, young workers may be less efficient in job search activities than adults. Younger workers are likely to have fewer contacts and less experience finding work, placing them at a relative disadvantage compared to adults. They may also find themselves in an experience trap, where employers select workers with experience, and as a result, labour market entrants are never hired and cannot increase their own experience. On the supply side, youths are less likely to have significant financial commitments than their elders. And their parents may be willing to support them should they not find work. Such factors may create an incentive to restrict their job search activity, leading to higher rates of unemployment. Whether the cause is on the demand or the supply side, the outcome is that youths experience considerably higher rates of unemployment than adults.

We proceed as follows. First, we examine the impact of Labour Market Programmes. Second we compare Greek youth unemployment with the experiences of seven other countries - France, Germany, Ireland, Portugal, Spain, Sweden and the UK. Third, we look at the treatment of students in labour market statistics. Fourth, we look at those Not in Employment, Education or Training (NEETS), some of whom are not picked up in the unemployment count. We then look at the rising trend among young people to continue living in the parental home. The next three sections look at 
underemployment, long-term unemployment and the well-being of the young. The final section draws some conclusions.

\section{Active Labour Market Programmes (ALMPs)}

In response to the substantial increases in youth unemployment during the 1980 s and early 1990s, there was a significant increase in policy initiatives targeted at unemployment in general and youth unemployment in particular. These culminated in the OECD Jobs Study (1994), which argued that policies to improve the working of the labour market were critical for reducing high levels of youth unemployment. It suggested that:

"A progressive shift of resources is needed from passive income support to active measures. Active labor market policies improve access to the labor market and jobs; develop job-related skills; and promote more efficient labor markets." (OECD Jobs Study 1994)

With OECD encouragement, many member countries introduced a range of active labour market policies (ALMPs). These were extensively evaluated to determine their labour market effects. In this context, "evaluation" tends to mean comparisons between those "treated" by a particular intervention and a comparable "control" group that are not "treated". Such evaluations can be described as partial equilibrium in the sense that they focus on a narrow range of outcomes (e.g. difference in the probability of finding full-time employment between the treated and untreated) in distinct subpopulations of the labour force. On the other hand, models that take a broader macroeconomic perspective tend to be insufficiently disaggregated to capture the general equilibrium impacts of ALMPs.

Even these partial equilibrium evaluations of ALMP impact have not shown them to be an unqualified success. Heckman and Smith (1999a, 1999b) examined the US Job Training Partnership Act (JTPA), which provided job-training services for economically disadvantaged adults and youth, dislocated workers and those facing significant employment barriers. They found that the estimates of the returns to training were sensitive to a) the set of training centers included in the evaluation, b) how outliers in the earnings data are handled, c) the construction of the earnings data, d) control group substitution and e) treatment group drop out. Even after these adjustments, they conclude that their results for youth "fit comfortably into the pattern of several decades of research that finds very limited earnings effects for the types of services offered by JTPA". In 1996, when asked by the Economist how much training schemes in the US help their clientele, Jim Heckman replied that 'zero is not a bad number' (Economist, 6th April, 1996).

Grubb (1999) is slightly more positive when reviewing US education and training programmes for disadvantaged youths. He argues that successful programmes embody some combination of the following characteristics:

i) Close links with the local labour market, targeting jobs with relatively high wages, strong employment growth and opportunities for advancement;

ii) A mix of academic education, occupational skills and on-the-job training; 
iii) Opportunities to enter further education, to further develop skills and competencies;

iv) Support services focused on the needs of clients and their families; and

v) Constant redesign of the programmes to learn from past experience.

Auspos et al. (1999) conclude that European ALMPs have not produced earnings gains for participants, but argue that smaller targeted schemes aimed at disadvantaged groups are more effective in raising employment than broad-based training programmes, particularly when used in conjunction with job search interventions. Successful programmes tend to be costly and may be difficult to expand broadly. Bergemann and van den Berg (2006) argue that training programmes are more effective for women than men in Europe. Focussing on youth, Calmfors et al. (2002) summarize the Swedish experience of ALMPs by arguing that youth programmes have caused substantial displacement effects, but the gains for participants are uncertain.

Card et al. (2009) carry out a meta-analysis of ALMPs. They examine 199 programmes drawn from 97 studies over the period 1995 to 2007. These are heterogeneous programmes covering classroom and work experience, job search assistance, and subsidized public and private employment programmes. Assessments of their short-run effects showed that the number of programmes with a significantly positive outcome only exceeds those with a significantly negative outcome by a small margin. Over longer time horizons, the balance is more in favour of positive outcomes. There are also significant differences between countries in the types of programmes which succeed or fail. There is no upward trend over time in positive outcomes. The evaluations contain little information on costs, making it difficult to establish how affordable large-scale expansion of successful programmes might be. The Card et al. study supports Grubb and Martin's (OECD 2001) conclusion that, "one of the most disappointing conclusions from the evaluation literature is that almost all evaluations show that special measures are not effective for disadvantaged youths."

In 2011, the EU launched the Youth Opportunities Initiative. This was added to in December 2012 by the Youth Employment Package. The Youth Employment Package proposed a youth guarantee, which the council recommended to the member states in April 2013. Specifically, the recommendation was that the member states of the European Union should "ensure that all young people under the age of 25 receive good quality offer of employment, continued education, apprenticeship or a traineeship with enough period of four months of becoming unemployed or leaving formal education" (Council of the European Union, 2013). The Council created the Youth Employment Initiative, through which $€ 6$ billion will be made available to NUTS 2 regions with a youth unemployment rate above $25 \%$ in 2012 . These monies have to be distributed between 2014 and 2016.

The Youth Guarantee is intended to provide young people with a job, training or education over a defined period. The entitlement is generally given by public institutions such as the public employment service, sometimes acting in concert with private or third sector organizations. The role of the public employment service varies by country within Europe. In many countries, private employment agencies have an increasing role alongside the public employment service. As Kluve (2010) notes, depending on the incentives that they face, private sector agencies are likely to focus on those that are relatively easy to place, leaving the public agencies with the more difficult 
cases, which are often characterized by social and health problems. Success with such groups will depend on the professionalisation and training of PES staff. Pastore (2013a) notes that in contrast to the Nordic countries, which is the model the Youth Guarantee is based on, private and public employment services in Southern European countries are very weak and concludes that this jeopardizes the chances of success for the Youth Guarantee in Southern Europe.

Greece is intending to implement a national youth action plan using $€ 517$ million, with the aim of benefiting up to 350,000 young people. Measures under the plan include a temporary hiring programme for unemployed persons below the age of 35 in communitybased work programmes. In July 2013, it introduced a youth internship and employment voucher programme under the youth action plan aimed at supporting occasional training and internships for a six-month period for 45,000 people up to the age of 29. A sum of $€ 1.2$ billion is being allocated to help small and medium-sized companies meet liquidity requirements and, thus, assist with the expansion of youth employment. It is too early to say whether any of these schemes are working or are likely to make any significant inroads into the youth unemployment problem if the main failure is a lack of aggregate demand.

\section{Greek youth unemployment in context; comparisons with seven other countries - France, Germany, Ireland, Portugal, Spain, Sweden and the UK}

In this section, we lay out some key facts on youth unemployment in Greece and place them in context. We do this from both a time-series and cross-sectional perspective. Specifically, we use aggregate data from Eurostat publications and micro-data from the 2005-2012 European Labour Force Survey to examine trends in unemployment, both in Greece itself and also in comparison with a selection of other European states. For these comparisons, we have selected Spain and Portugal as Southern European countries that, like Greece, have experienced serious monetary disturbances as well as labour market dislocation. Although it is not in Southern Europe, we include the Republic of Ireland for the same reasons. Though having a stable macroeconomic framework in recent years, Sweden has experienced persistently high levels of youth unemployment, especially relative to adult rates, and has also been included. Finally, we add the three largest countries in Europe - Germany, the UK and France - to give a perspective on unemployment trends in the European Union as a whole. These countries also span a variety of experiences during the recession, including wide variations in labour market performance. A referee has pointed out to us that, these eight countries span quite different school-to-work transition patterns: a) France, Greece, Spain, Portugal are the Mediterranean rim; b) Sweden represents the Scandinavian model; c) UK and Ireland represent the Anglo-Saxon model; and d) Germany is an example of the Central European or Bismarckian model.

The conventional measure of "youth" is the age group 16-24. However, there is a strong case for arguing that the labour market experience of "young adults" aged 25-29 in 2014 is quite similar to that of youth during the Great Recession. This is appropriate because these individuals in their late twenties were 19-23 in 2008 when the recession hit. Where we can, we also include information for this age group. The age group differences are captured in Figures 1 and 2, which show unemployment rates and employment to population ratios, respectively, for 15-19, 20-24 and 25 to 29-year-olds. These capture the extent of the unemployment problem and the weakness of the Greek 


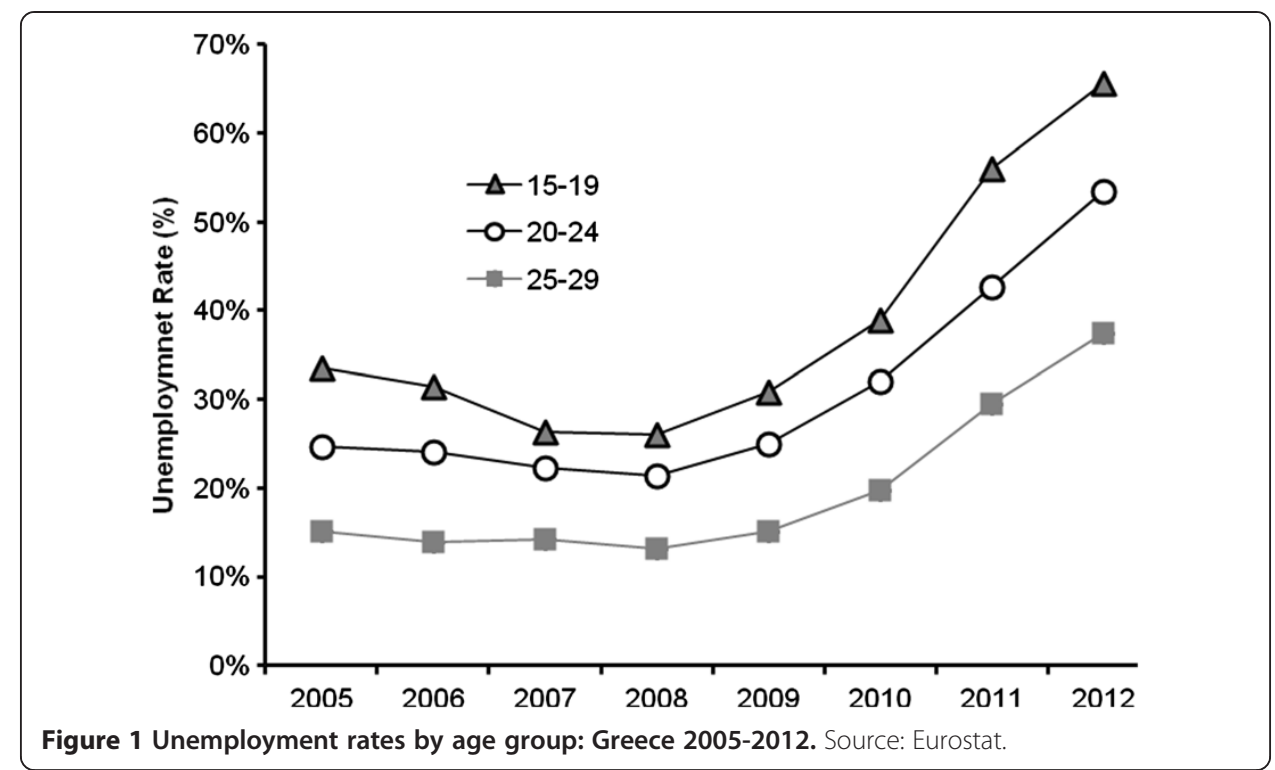

labour market for young people. The unemployment rates for youth in particular have captured worldwide attention and are deemed to be a potential cause of social instability. However, Figures 1 and 2 also show that the Greek labour market is not working well for 25 to 29-year-olds. Though the increase between 2005 and 2012 in the unemployment rate of this group (22 per cent) was smaller than that of 20 to 24year-olds ( 29 per cent) and of 15 to 19-year-olds (32 per cent), the 25-29 age group experienced the largest fall in the employment to population ratio over the period: a larger proportion of this age group became unemployed or inactive between 2005 and 2012 compared to 15 to 19 -year-olds and 20 to 24 -year-olds.

Figures 1 and 2 focus on differences in labour market outcomes by age group. Table 2 contains the information which explains how differences in rates relate to the absolute numbers of employed, unemployed and inactive by age group. It also introduces the gender dimension, which is an important source of variation in the labour market experience of young people in Greece. Thus, the top panel of Table 2 shows population,

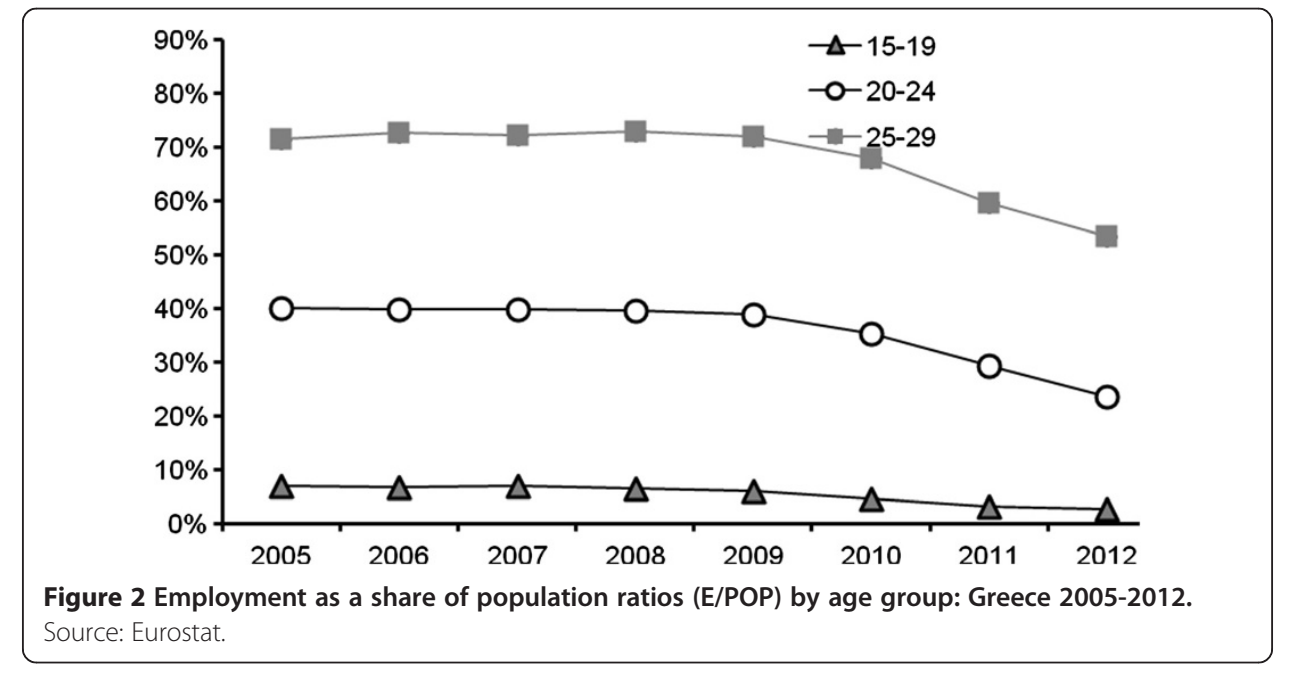


Table 2 Population, employment and unemployment by year, age group and gender: Greece 2005-2012 (Thousands)

\begin{tabular}{|c|c|c|c|c|c|c|c|c|c|c|c|c|c|c|c|c|c|c|}
\hline \multirow[b]{3}{*}{ Age } & \multicolumn{6}{|c|}{ Population } & \multicolumn{6}{|c|}{ Employment } & \multicolumn{5}{|c|}{ Unemployment } & \\
\hline & \multicolumn{3}{|c|}{ Males } & \multicolumn{3}{|c|}{ Females } & \multicolumn{3}{|c|}{ Males } & \multicolumn{3}{|c|}{ Females } & \multicolumn{3}{|c|}{ Males } & \multicolumn{3}{|c|}{ Females } \\
\hline & $15-19$ & $20-24$ & $25-29$ & $15-19$ & $20-24$ & $25-29$ & $15-19$ & $20-24$ & $25-29$ & $15-19$ & $20-24$ & $25-29$ & $15-19$ & $20-24$ & $25-29$ & $15-19$ & $20-24$ & $25-29$ \\
\hline \multicolumn{19}{|l|}{ Year } \\
\hline 2005 & 281 & 333 & 408 & 281 & 334 & 389 & 26 & 159 & 335 & 13 & 109 & 235 & 8 & 34 & 37 & 11 & 54 & 64 \\
\hline 2006 & 287 & 323 & 415 & 289 & 314 & 382 & 27 & 154 & 341 & 13 & 100 & 240 & 9 & 30 & 37 & 9 & 51 & 58 \\
\hline 2007 & 281 & 309 & 419 & 287 & 295 & 377 & 27 & 146 & 340 & 13 & 95 & 236 & 6 & 26 & 41 & 8 & 44 & 55 \\
\hline 2008 & 273 & 304 & 410 & 285 & 285 & 373 & 23 & 141 & 335 & 13 & 93 & 237 & 6 & 28 & 37 & 7 & 36 & 50 \\
\hline 2009 & 270 & 294 & 404 & 278 & 280 & 362 & 22 & 134 & 321 & 11 & 90 & 230 & 6 & 31 & 44 & 8 & 43 & 53 \\
\hline 2010 & 273 & 280 & 381 & 267 & 282 & 358 & 16 & 119 & 289 & 9 & 80 & 215 & 9 & 41 & 56 & 8 & 53 & 67 \\
\hline 2011 & 280 & 266 & 377 & 270 & 271 & 342 & 13 & 94 & 250 & 5 & 65 & 180 & 12 & 55 & 88 & 11 & 63 & 92 \\
\hline 2012 & 275 & 265 & 366 & 271 & 266 & 325 & 11 & 76 & 211 & 4 & 50 & 159 & 14 & 67 & 116 & 15 & 77 & 106 \\
\hline \multicolumn{7}{|c|}{ Activity Rate (\%) } & \multicolumn{6}{|c|}{ EPOP Rate (\%) } & \multicolumn{6}{|c|}{ Unemployment Rate (\%) } \\
\hline 2005 & 12 & 58 & 91 & 9 & 49 & 77 & 9 & 48 & 82 & 5 & 33 & 60 & 24 & 18 & 10 & 46 & 33 & 21 \\
\hline 2006 & 13 & 57 & 91 & 7 & 48 & 78 & 9 & 48 & 82 & 4 & 32 & 63 & 25 & 16 & 10 & 42 & 34 & 19 \\
\hline 2007 & 12 & 56 & 91 & 7 & 47 & 77 & 9 & 47 & 81 & 5 & 32 & 63 & 19 & 15 & 11 & 37 & 31 & 19 \\
\hline 2008 & 11 & 56 & 91 & 7 & 45 & 77 & 9 & 46 & 82 & 5 & 33 & 64 & 19 & 17 & 10 & 36 & 28 & 17 \\
\hline 2009 & 11 & 56 & 90 & 7 & 48 & 78 & 8 & 46 & 79 & 4 & 32 & 64 & 22 & 19 & 12 & 43 & 33 & 19 \\
\hline 2010 & 9 & 57 & 91 & 6 & 47 & 79 & 6 & 43 & 76 & 3 & 28 & 60 & 35 & 25 & 16 & 45 & 40 & 24 \\
\hline 2011 & 9 & 56 & 90 & 6 & 47 & 80 & 5 & 35 & 66 & 2 & 24 & 53 & 48 & 37 & 26 & 68 & 49 & 34 \\
\hline 2012 & 9 & 54 & 89 & 7 & 48 & 82 & 4 & 29 & 58 & 1 & 19 & 49 & 56 & 47 & 35 & 79 & 61 & 40 \\
\hline
\end{tabular}


employment and unemployment by 5-year age group and gender for the period 2005 to 2012 in thousands. The bottom panel shows equivalent activity rates, employment to population ratios, and unemployment rates based on these numbers.

Though 15-19 year olds have the highest unemployment rates in 2012 (56\% for males and $79 \%$ for females), this age group has low, and declining, rates of labour market participation between 2005 and 2012. When levels of participation are low, high unemployment rates can be consistent with relatively small absolute numbers of unemployed people. This is the case for this age group. Employment to population ratios are much higher among those aged 25-29, and unemployment rates are lower than among the younger age groups.

With Greece, as in most developed countries, inactivity tends to decline with age up to around age 30 as individuals move from education into the labour market. Without information on participation, high unemployment rates may give a misleading impression of absolute levels of unemployment. Despite the fact that the unemployment rate for 25 to 29 -year-olds was only 57 per cent of that for 15 to 19 -year-olds, there were 7.7 unemployed persons aged 25-29 for each unemployed person aged 15-19 in 2012. And the absolute numbers unemployed in the $25-29$ age group $(222,000)$ exceeded the number unemployed in the entire $16-24$ age group $(173,000)$ by 28 per cent. This suggests that policy focus on the 16 to 24-year-olds may have to be supplemented by measures aimed at 25 to 29 -year-olds to have a significant impact on unemployment among young people (broadly defined) in Greece.

The size of the youth cohort in Greece is declining. Between 2005 and 2012, the Greek population aged 15-19 fell by 2.8 per cent. The number in the 20-24 age group fell by 20.5 per cent, while those aged $25-29$ fell by 13.4 per cent. This is a staggering decline over such a short period. It represents the effects of falling cohort size (as among the relatively immobile 15 to 19 -year-olds) and net emigration, which explains the much greater reduction in cohort size among the more mobile 20 to 29-year-olds. It appears that there is going to be a rapid decline in the number of young Greeks through 2020 (See Figure 3).

There are surprising differences in population trends by gender. First, whereas numbers of males and females in the population are broadly balanced in the 15-19 and 20-24 categories, as one would expect, there appears to be a growing imbalance between those in the 25-29 age group, with the number of males exceeding females by

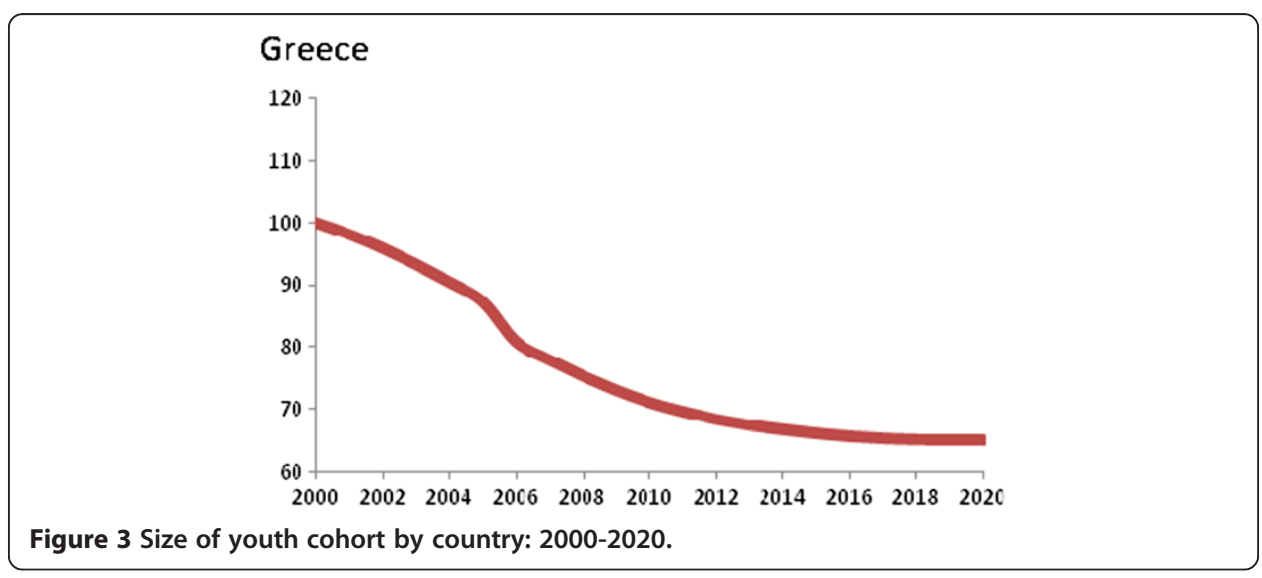


around 40,000 in 2012. This may be due to higher levels of net emigration by females. In turn, higher emigration rates may be a response to poorer labour outcomes for females. Female activity rates and employment to population ratios are consistently lower, and unemployment rates higher, than those for males in the Greek labour market. In 2012, the unemployment rate for females aged 15-19 was $23 \%$ above that for males, while for those aged 20-24 and 25-29, the equivalent margins were $14 \%$ and $5 \%$. Female youth unemployment rates are significantly higher than those for males. In this respect, Greece is an outlier among our selection of nations, as is clear from Figure 4, which shows the ratio of female to male youth unemployment rates in each country for the period 2005 to 2012.

It should be noted, though, that in contrast to the United States and Canada, where male rates are higher than female rates, female unemployment rates are higher than male rates in both the EU and the Eurozone; this seems particularly the case in Southern Europe. In the latest data release from Eurostat, female unemployment rates were higher than male unemployment rates in ten countries: Austria, Czech Republic, Greece, Hungary, Italy, Luxembourg, Poland, Portugal, Slovenia and Spain. ${ }^{1}$ Though there is clearly a tendency towards convergence of youth unemployment rates by gender between 2012 and 2015, southern European countries typically have female youth unemployment rates that are significantly higher than their male equivalents, with Greece being the most extreme case. The ratio has narrowed since the beginning of the recession, but it still exceeds those in our comparison countries. The large number of females among the unemployed may have conditioned the social and political response.

The issue of the relative importance of youth unemployment is generally addressed by considering the ratio of the youth unemployment to the adult rate (where adults are usually defined as the age group from age 25 to age 64). Figure 5 shows both the youth unemployment rate and this ratio for each of our eight countries for available time periods. As mentioned previously, there are a variety of reasons why one would expect

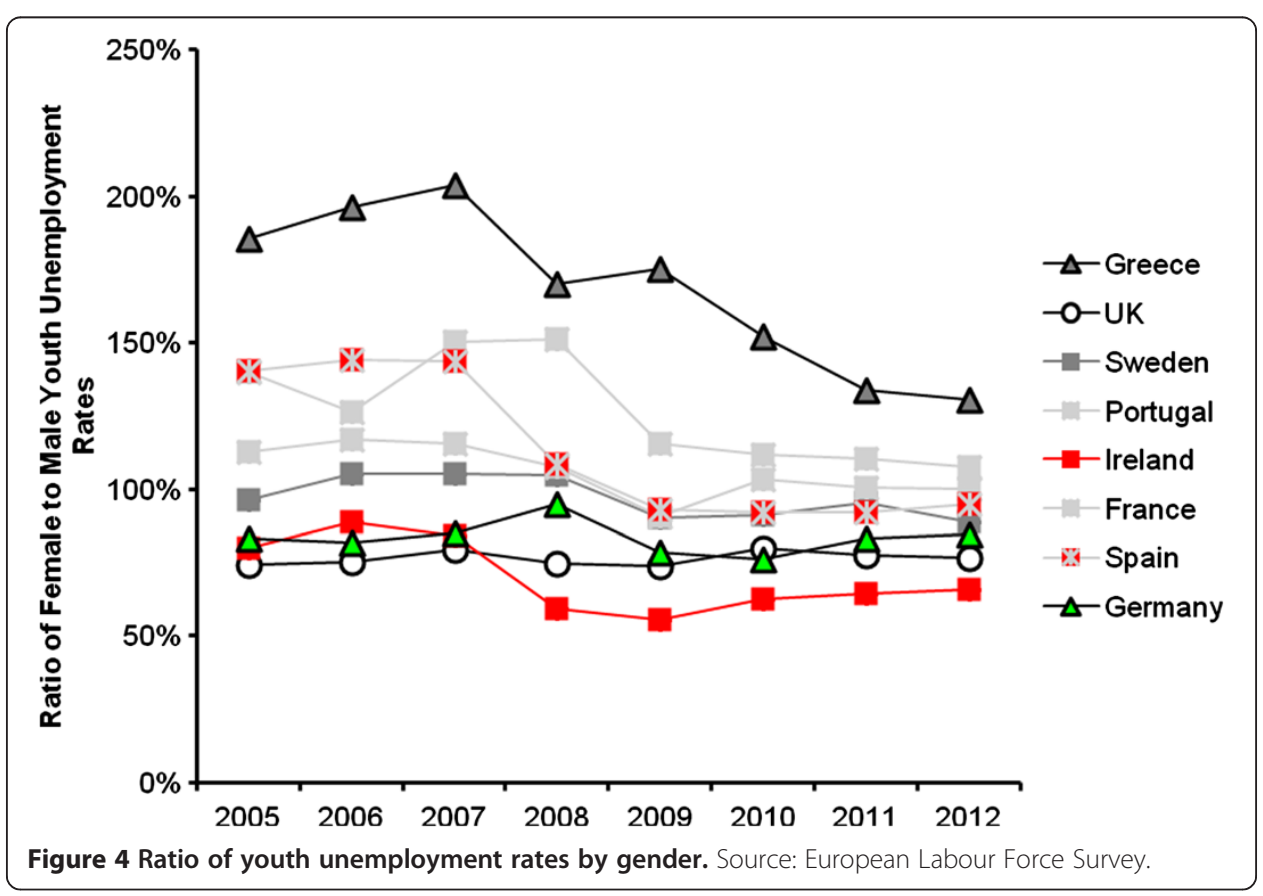




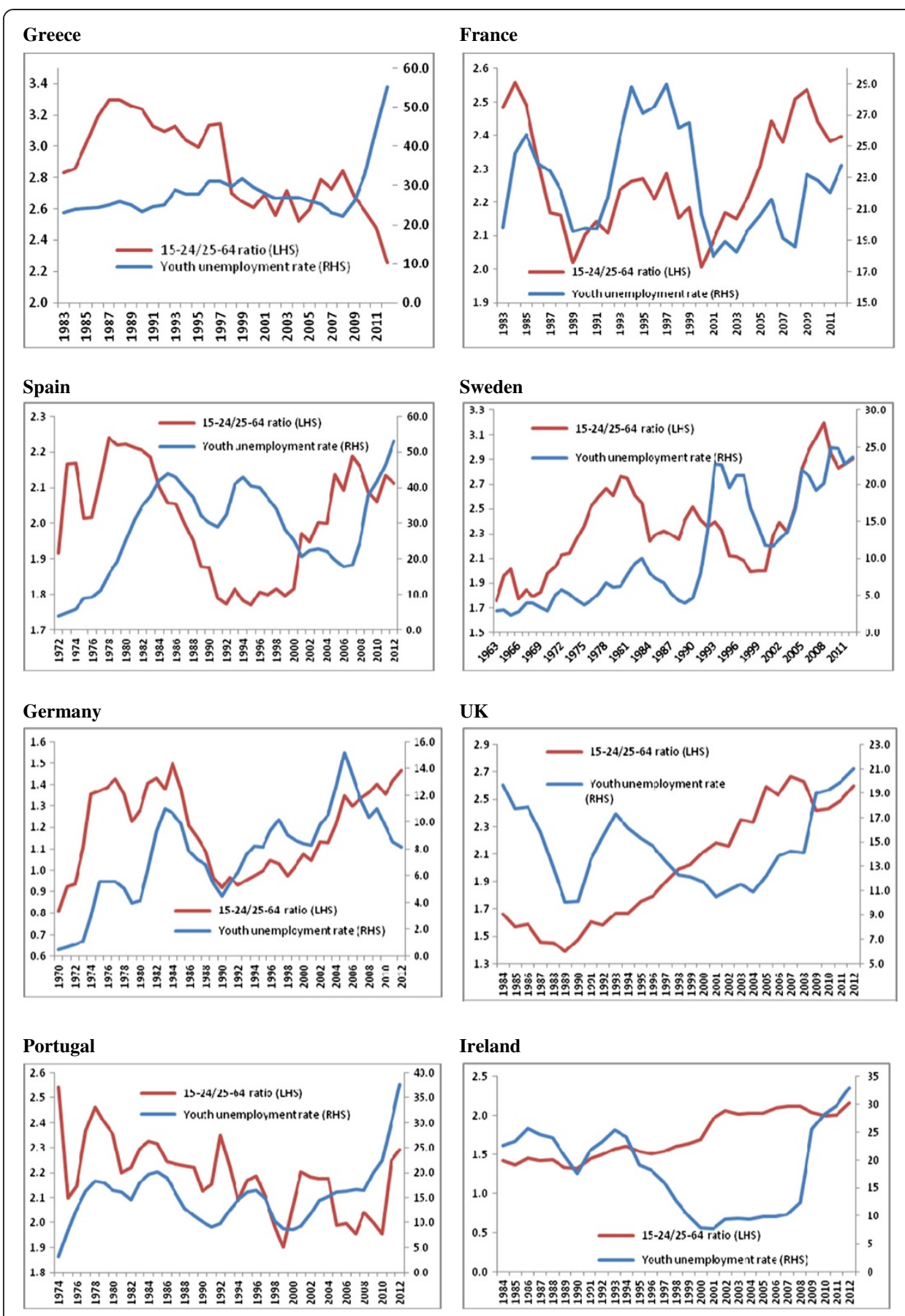

Figure 5 Youth unemployment rates and ratios. Source: $O E C D$.

youth unemployment rates would be higher than adult rates. But there are also very substantial differences between countries in the ratio of youth to adult unemployment, which suggests a significant degree of variation between countries in the circumstances facing new entrants to the labour market compared with incumbents. It is not the case that the countries with the highest youth unemployment rates also have the highest ratios of adult to youth unemployment. In 2012, Sweden (2.9) and the UK (2.6) had somewhat higher ratios than did Greece (2.3). Spain (2.1) and Portugal (2.3) also had 
relatively low youth to adult unemployment rate ratios. The concern is that social unrest can occur, as it has in both the UK and Sweden, where relative youth unemployment rates are especially high. It is OK if everyone is in it together but not if the young seem in a much worse situation than everyone else. In the case of Sweden, the unrest occurred especially among immigrants.

\section{Students}

Under ILO definitions, full-time students may be classified as employed or unemployed. Their ability to operate in the labour market is more constrained than their non-student peers. Typically they work part-time during term or perhaps full-time during vacations. Students who work part-time are counted as employed by standard ILO definitions; students who are looking for work are similarly counted as unemployed.

Student participation in the labour market tends to focus on meeting short-term living costs rather than long-term career aspirations. Comparisons of youth unemployment over time or across countries can be influenced by the extent of participation in tertiary education. Participation will be affected both by the supply of places and the opportunity costs of attendance. The interaction between student and labour market status is shown in Table 3, which compares labour market and educational status in Greece, for simplicity, with the UK in 2012. We present numbers (in thousands) employed, unemployed and inactive alongside the unemployment for the age group 1529. We provide these estimates separately for students and non-students. It is apparent that, in Greece, few students are also participating (part-time) in the labour force, whereas this is a major phenomenon in, for example, the UK.

Unemployment rates for students are somewhat higher than are those for nonstudents in both Greece and the UK. However, this has little effect on the overall unemployment rate in Greece because relatively few students are involved in the labour market. Similar observations can be made about Portugal and Spain, which have relatively high student unemployment rates that have little impact on the overall youth unemployment rate because student participation in the labour market is limited. Overall, students account for nearly double the share of employment (24.4\%) in northern European countries - Sweden, the UK, Ireland, France and Germany - than they do in the southern countries - Greece, Spain and Portugal (12.5\%).

\section{Those Not in Employment, Education or Training (NEETS)}

Table 3 and Figure 6 also provide information on NEETS - those not in employment, education or training. These comprise the unemployed plus inactive non-students. Their number can be calculated and expressed as a share of the population, which gives the NEET "rate" as shown for each country panel in Table 3. NEETs comprise a much larger share of the population in Greece than, for example, in the UK, Germany or France. NEET rates in Greece exceed those in other crisis hit countries such as Spain, Portugal and Ireland. The inactive members of this group present a more difficult policy challenge since they are not actively seeking work, not enhancing their specific or general human capital, and not improving their strategies for engagement with the labour market. The NEET rate in Greece has overtaken that in many other European economies. Figure 7 plots the per cent of NEETS by the two young age groups 15-19 and 20-24 for each of our eight countries. The unemployment rate for the youngest age group, 
Table 3 Unemployment, NEET and educational status in selected European countries among those aged 16-29, 2012 (thousands)

\begin{tabular}{|c|c|c|c|c|c|c|c|c|c|c|c|}
\hline Greece & Student & Non-student & Total & Portugal & Student & Non-student & Total & Spain & Student & Non-student & Total \\
\hline Employed & 32 & 479 & 511 & Employed & 89 & 652 & 742 & Employed & 346 & 2,120 & 2,466 \\
\hline Unemployed & 36 & 359 & 396 & Unemployed & 57 & 224 & 281 & Unemployed & 372 & 1,394 & 1,766 \\
\hline Inactive & 729 & 131 & 860 & Inactive & 681 & 94 & 776 & Inactive & 2,674 & 519 & 3,193 \\
\hline Total & 676 & 970 & 1,646 & Total & 701 & 970 & 1,671 & Total & 3,016 & 4,033 & 7,049 \\
\hline Unemployment Rate & $53.5 \%$ & $42.8 \%$ & $43.6 \%$ & Unemployment Rate & $38.8 \%$ & $25.5 \%$ & $27.4 \%$ & Unemployment Rate & $51.8 \%$ & $39.7 \%$ & $41.7 \%$ \\
\hline NEET Rate & & & $27.8 \%$ & NEET Rate & & & $17.7 \%$ & NEET Rate & & & $25.8 \%$ \\
\hline Germany & Student & Non-student & Total & France & Student & Non-student & Total & Sweden & Student & Non-student & Total \\
\hline Employed & 2,797 & 5,423 & 8,221 & Employed & 793 & 4,224 & 5,017 & Employed & 229 & 731 & 960 \\
\hline Unemployed & 127 & 517 & 644 & Unemployed & 92 & 1,004 & 1,096 & Unemployed & 92 & 110 & 202 \\
\hline Inactive & 4,646 & 863 & 5,509 & Inactive & 4,208 & 885 & 5,093 & Inactive & 582 & 93 & 675 \\
\hline Total & 7,416 & 6,803 & 14,218 & Total & 5,093 & 6,113 & 11,206 & Total & 819 & 934 & 1,753 \\
\hline Unemployment Rate & $4.3 \%$ & $8.7 \%$ & $7.3 \%$ & Unemployment Rate & $10.4 \%$ & $19.2 \%$ & $17.9 \%$ & Unemployment Rate & $28.7 \%$ & $13.0 \%$ & $17.4 \%$ \\
\hline NEET Rate & & & $9.6 \%$ & NEET Rate & & & $16.9 \%$ & NEET Rate & & & $11.0 \%$ \\
\hline Ireland & Student & Non-student & Total & UK & Student & Non-student & Total & & & & \\
\hline Employed & 71 & 315 & 386 & Employed & 1,422 & 5,733 & 7,154 & & & & \\
\hline Unemployed & 14 & 102 & 116 & Unemployed & 312 & 992 & 1,304 & & & & \\
\hline Inactive & 299 & 92 & 391 & Inactive & 2,985 & 1,019 & 4,004 & & & & \\
\hline Total & 333 & 509 & 842 & Total & 4,591 & 7,744 & 12,335 & & & & \\
\hline \multirow[t]{2}{*}{ Unemployment Rate } & $16.7 \%$ & $24.5 \%$ & $23.2 \%$ & Unemployment Rate & $18.0 \%$ & $14.8 \%$ & $15.4 \%$ & & & & \\
\hline & & & $21.7 \%$ & NEET Rate & & & $16.1 \%$ & & & & \\
\hline
\end{tabular}




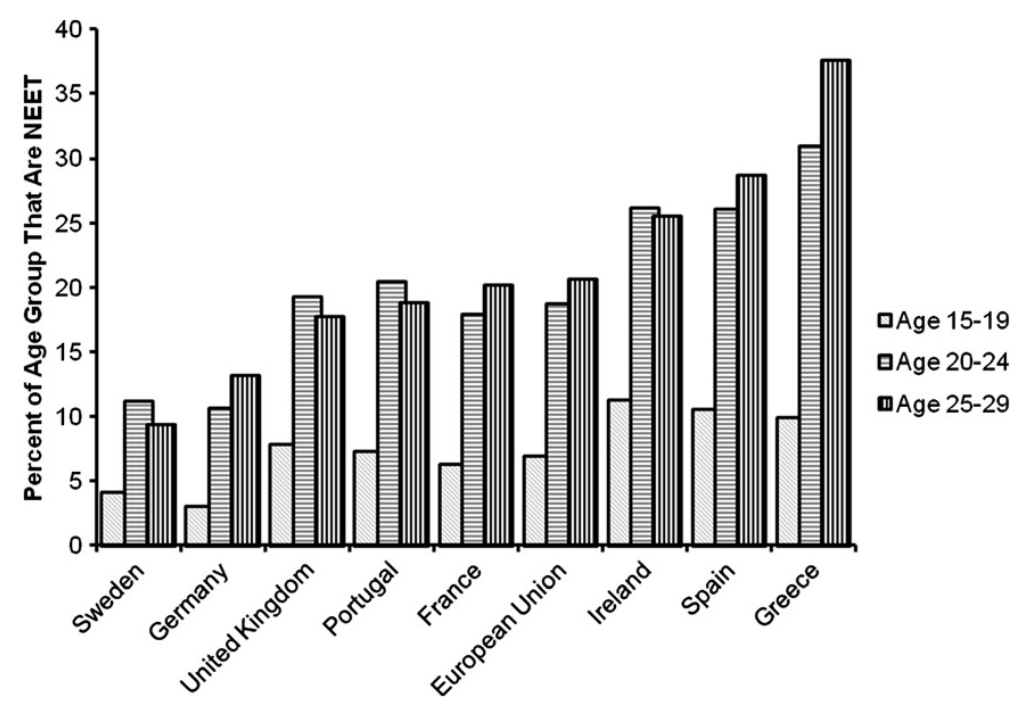

Figure 6 Percent NEET (Not in Employment, Education or Training) by country and age group 2013. Source: Eurostat.

those aged 15-19, is lower in Greece than in both Spain and Ireland, while the two older groups have higher unemployment rates than in any of the other countries. The NEETs problem in Greece looks to require urgent attention, but it is also relatively intractable. As mentioned in our discussion of ALMPs, private sector agencies tend to avoid the most hard to reach cases, and the public sector may not have the resources to support the level of intervention necessary to match such individuals with employment opportunities.

\section{Living in the parental home}

How far are the costs of unemployment or inactivity mitigated by remaining in the parental home? There are substantial differences across Europe in the extent to which parents and children are willing to share accommodation once a child has completed secondary education. Compared with other Europeans, Greeks shows a high willingness to maintain inter-generational households. Table 4 shows the relationship of individuals in the 15-24 age group that are unemployed or inactive to the household reference

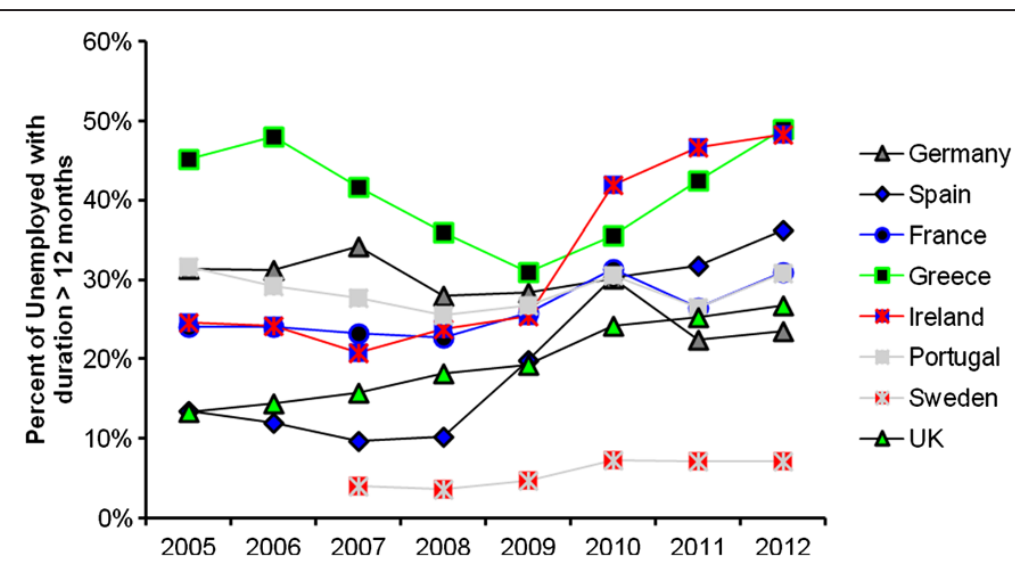

Figure 7 Share of unemployed out of work for more than one year. Source: Eurostat. 
Table 4 Proportion of those aged 15-29 with parents not in the same household

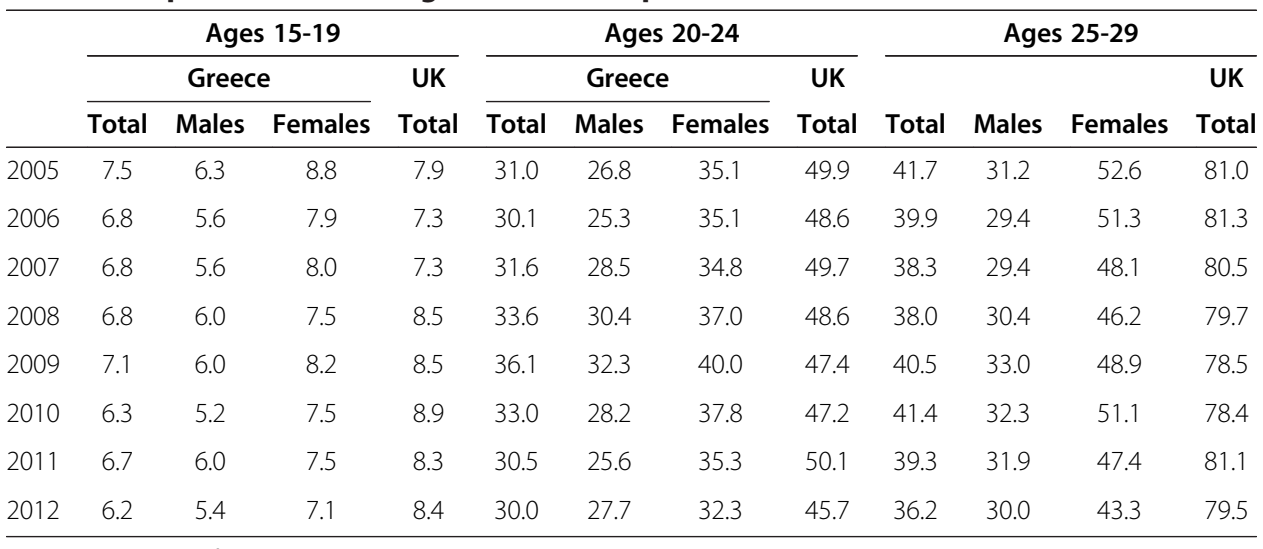

Source: European Labour Force Survey.

person before and after 2008 in Greece and the UK. We report the proportion of those aged 15-19, 20-24 and 25-29 who are not living with their parents from 2005 to 2012. We see very little change for the youngest two age groups: all the action is for the older group aged $25-29$. In the UK, the proportion falls slightly from $81 \%$ to $80 \%$, but in Greece it falls from $42 \%$ to $32 \%$. So, only one out of three 25 to 29 -year-olds in Greece live away from home, whereas in the UK, four out of five have left home. In part, this is likely to reflect lack of jobs but also in part the inflexibility of the housing market. Blanchflower and Oswald (2012) found that the highest home ownership rates in the OECD are in Spain and Greece; unemployment appears to be positively correlated with home ownership rates. Of particular importance here then is the lack of a private rental sector that allows young people to move to where the jobs are. The housing market is a major rigidity impacting the Greek labour market, in that it appears to lower mobility.

To explore these issues further, in Table $5^{2}$, we compare likelihoods of living away from home among those aged 15-29 in Greece and the other seven countries by gender over the period 2005-2012. The purpose is to investigate whether there were significant differences by age group, gender, employment status and across country in propensity to stay with parents. Assuming that parents do not move to facilitate the employment prospects of the young, the effects of staying at home may be to reduce the costs of unemployment or inactivity on the one hand, but to restrict opportunities for searching on the other. We estimated probit regressions where living away from the parental home is the dependent variable. We include two age controls and dummies for whether the individual is a NEET, a student, for the recession years 2008-2012 and an interaction term recession*NEET. We find that, in Greece, and to an even greater extent in Spain and Portugal, the probability of 20 to 24-year-olds, and to a lesser extent 25 to 29-year-olds, living with their parents is significantly higher than in the other five countries included in our comparison group, including Ireland. For example, in Greece, the probability of a 25 to 29 -year-old male not living with their parents is $45 \%$ (55\%) higher than for 15 to 19-year-olds, compared with 20\% (28\%) in Portugal and 23\% (33\%) in Spain (females rates in parentheses). So females are more likely to have left home in these three countries than are males. In France, Germany and the UK, around 70\% of both males and females aged 25-29 had left home, so in these countries, there was little evidence of substantial gender differences in the home leaving rate. Table 6 explores 
Table 5 Dprobit of likelihood of parents not being in same household as child, 2005-2012

\begin{tabular}{|c|c|c|c|c|c|c|c|c|c|c|c|c|c|c|}
\hline & \multicolumn{2}{|c|}{ Greece } & \multicolumn{2}{|c|}{ UK } & \multicolumn{2}{|c|}{ Portugal } & \multicolumn{2}{|c|}{ Ireland } & \multicolumn{2}{|c|}{ France } & \multicolumn{2}{|c|}{ Spain } & \multicolumn{2}{|c|}{ Germany } \\
\hline & Males & Females & Males & Females & Males & Females & Males & Females & Males & Females & Males & Females & Males & Females \\
\hline Age 20-24 & 0.383 & 0.414 & 0.489 & 0.509 & 0.042 & 0.091 & 0.343 & 0.418 & 0.394 & 0.415 & 0.075 & 0.128 & 0.439 & 0.488 \\
\hline Age 25-29 & 0.445 & 0.550 & 0.735 & 0.724 & 0.195 & 0.281 & 0.589 & 0.661 & 0.687 & 0.666 & 0.229 & 0.324 & 0.696 & 0.706 \\
\hline Recession & 0.009 & 0.004 & $0.002^{\circ}$ & -0.014 & $-0.005^{\circ}$ & 0.010 & 0.117 & 0.121 & $-0.004^{\circ}$ & -0.020 & $0.001^{\circ}$ & 0.014 & 0.029 & 0.024 \\
\hline NEET & -0.118 & 0.121 & -0.044 & 0.215 & -0.060 & 0.052 & -0.078 & 0.103 & -0.160 & -0.020 & -0.041 & 0.049 & -0.017 & 0.138 \\
\hline Recession*NEET & 0.022 & -0.054 & -0.014 & -0.026 & $0.029^{\circ}$ & -0.026 & -0.043 & -0.033 & -0.018 & -0.020 & 0.016 & -0.028 & -0.041 & $-0.017^{\circ}$ \\
\hline Student & 0.139 & 0.115 & 0.009 & -0.086 & -0.107 & -0.164 & -0.060 & -0.088 & -0.137 & -0.269 & -0.104 & -0.166 & -0.133 & -0.223 \\
\hline$n=$ & 189007 & 182334 & 75991 & 80788 & 120182 & 113201 & 128675 & 130803 & 298121 & 300694 & 127726 & 122139 & 106057 & 103613 \\
\hline Pseudo $R^{2}=$ & 0.112 & 0.131 & 0.292 & 0.362 & 0.144 & 0.181 & 0.229 & 0.273 & 0.312 & 0.368 & 0.174 & 0.217 & 0.287 & 0.368 \\
\hline
\end{tabular}


the issue of why females ages 25-29 are less likely than males of the same age to be living with their parents. In part this is because females are more likely to be married.

Lack of mobility seems to be a major issue in Greece, presumably in part due to rigidities in the housing market.

\section{Underemployment}

It also appears that if young people have jobs, they tend to be underemployed (Bell and Blanchflower 2011a) ${ }^{3}$. Youngsters are faced with a double whammy, their job is more likely to be temporary rather than permanent and to have less hours than they would like. Table 7 documents the rise in the share of the young in temporary employment, despite the fact that the incidence of temporary employment itself is broadly unchanged across the OECD and in most countries. The increase between 2008 and 2013 is especially marked in Spain, where it rose from 59\% to 65\%, although it has fallen slightly in Greece. Table 8 shows the change in the share of involuntary part-time employment among the young. This increased from $8 \%$ to $23 \%$ in Spain and from 5\% to $11 \%$ in Greece. The young appear to be disproportionately unemployed and, if they do have jobs, to be underemployed.

\section{Duration of unemployment and underemployment}

We now turn to other dimensions of the youth unemployment problem. Figure 8 reports the shares of the unemployed who have been continuously unemployed for at least a year, which are especially high in Ireland and Greece. We know from Ellwood (1984) that long spells of unemployment while young causes permanent scars rather than the temporary blemishes they cause for other age groups. Interestingly though, Figure 9 shows that the average age of the long-term unemployed is lower in the UK

Table 6 Percent single by economic status ages 25-29 between 2009 and 2012 (\%)

\begin{tabular}{|c|c|c|c|c|}
\hline & Employed & Unemployed & Inactive & Total \\
\hline \multicolumn{5}{|l|}{ Males } \\
\hline Greece & 83.3 & 90.6 & 97.7 & 86.2 \\
\hline Spain & 84.6 & 88.8 & 94.9 & 86.7 \\
\hline Portugal & 71.1 & 82.0 & 94.6 & 75.1 \\
\hline Ireland & 83.1 & 87.6 & 90.4 & 84.8 \\
\hline Germany & 80.7 & 87.1 & 93.3 & 82.9 \\
\hline France & 83.4 & 86.4 & 90.4 & 84.3 \\
\hline Sweden & 86.3 & 83.7 & 91.4 & 86.7 \\
\hline UK & 75.2 & 88.1 & 87.6 & 77.3 \\
\hline \multicolumn{5}{|l|}{ Females } \\
\hline Greece & 73.0 & 77.7 & 37.9 & 66.9 \\
\hline Spain & 75.1 & 73.2 & 56.7 & 71.7 \\
\hline Portugal & 59.8 & 62.8 & 61.5 & 60.4 \\
\hline Ireland & 77.8 & 79.6 & 69.2 & 76.1 \\
\hline Germany & 74.8 & 72.0 & 52.1 & 69.9 \\
\hline France & 77.2 & 79.3 & 60.4 & 74.3 \\
\hline Sweden & 79.9 & 69.8 & 66.5 & 76.7 \\
\hline UK & 70.0 & 79.4 & 60.9 & 68.5 \\
\hline
\end{tabular}


Table 7 Incidence of temporary employment

\begin{tabular}{|c|c|c|c|c|}
\hline & \multicolumn{2}{|c|}{ Share of total employment } & \multicolumn{2}{|c|}{ 15-24 share of temporary employment } \\
\hline & 2008 & 2013 & 2008 & 2013 \\
\hline Australia & 6 & 6 & 6 & 6 \\
\hline Austria & 9 & 9 & 35 & 35 \\
\hline Belgium & 8 & 8 & 29 & 33 \\
\hline Canada & 12 & 13 & 27 & 30 \\
\hline Chile & 31 & 30 & 48 & 46 \\
\hline Czech Republic & 8 & 10 & 16 & 29 \\
\hline Denmark & 9 & 9 & 24 & 21 \\
\hline Estonia & 2 & 4 & 6 & 12 \\
\hline Finland & 15 & 16 & 40 & 43 \\
\hline France & 15 & 17 & 53 & 59 \\
\hline Germany & 15 & 13 & 57 & 53 \\
\hline Greece & 11 & 10 & 29 & 27 \\
\hline Hungary & 8 & 11 & 20 & 25 \\
\hline Iceland & 10 & 14 & 28 & 34 \\
\hline Ireland & 8 & 10 & 22 & 33 \\
\hline Italy & 13 & 13 & 43 & 53 \\
\hline Japan & 14 & 14 & 26 & 27 \\
\hline Korea & 24 & 22 & 29 & 27 \\
\hline Luxembourg & 6 & 7 & 39 & 31 \\
\hline Netherlands & 18 & 21 & 45 & 53 \\
\hline Norway & 9 & 8 & 26 & 24 \\
\hline Poland & 27 & 27 & 63 & 69 \\
\hline Portugal & 23 & 22 & 54 & 61 \\
\hline Slovak Republic & 5 & 7 & 13 & 21 \\
\hline Slovenia & 17 & 16 & 70 & 74 \\
\hline Spain & 29 & 23 & 59 & 65 \\
\hline Sweden & 16 & 17 & 54 & 56 \\
\hline Switzerland & 13 & 13 & 51 & 52 \\
\hline Turkey & 11 & 12 & 13 & 20 \\
\hline United Kingdom & 5 & 6 & 12 & 15 \\
\hline Russian Federation & 14 & 9 & 24 & 17 \\
\hline Latvia & 3 & 4 & 7 & 10 \\
\hline Europe & 15 & 14 & 39 & 41 \\
\hline OECD countries & 12 & 12 & 25 & 25 \\
\hline
\end{tabular}

Source: OECD: Notes Date for Australia \& Japan for 2012 not 2013.

than in any other country, and it is lower in Greece than in France, Spain, Portugal, Sweden or Germany. Figure 10 makes clear that the highest proportion of female longterm unemployed is in Greece.

Table 9 reports the results of estimating a probit column for Greece only where the dependent variable is set to one if the individual has been unemployed for at least a year (LTU), and 0 otherwise (employed and $<1$ year unemployed). An unemployment column is also reported. Separate results are reported for those aged 16-64 and then for youngsters aged 16-29. There are nearly a million observations in the larger sample 
Table 8 Share or involuntary part-time employment in total employment, 15 to 24-yearolds

\begin{tabular}{|c|c|c|c|}
\hline & 2008 & 2010 & 2012 \\
\hline Australia & 13 & 16 & 16 \\
\hline Austria & 2 & 2 & 1 \\
\hline Belgium & 6 & 5 & 4 \\
\hline Canada & 7 & 10 & 10 \\
\hline Czech Republic & 0 & 1 & 1 \\
\hline Denmark & 3 & 5 & 4 \\
\hline Finland & 7 & 9 & 8 \\
\hline France & 7 & 8 & 8 \\
\hline Germany & 4 & 3 & 2 \\
\hline Greece & 5 & 8 & 11 \\
\hline Hungary & 1 & 2 & 3 \\
\hline Ireland & 2 & 10 & 13 \\
\hline Italy & 9 & 13 & 17 \\
\hline Japan & 7 & 10 & 7 \\
\hline Luxembourg & 1 & 1 & 3 \\
\hline Netherlands & 2 & 2 & 4 \\
\hline New Zealand & 9 & 11 & 11 \\
\hline Norway & 1 & 2 & 2 \\
\hline Poland & 1 & 2 & 3 \\
\hline Portugal & 4 & 6 & 8 \\
\hline Slovak Republic & 1 & 4 & 4 \\
\hline Spain & 8 & 14 & 23 \\
\hline Sweden & 9 & 11 & 11 \\
\hline United Kingdom & 4 & 7 & 9 \\
\hline United States & 3 & 5 & 6 \\
\hline European Union 15 & 5 & 7 & 7 \\
\hline Europe & 4 & 5 & 5 \\
\hline G7 countries & 4 & 7 & 6 \\
\hline OECD countries & 3 & 5 & 5 \\
\hline
\end{tabular}

Source: OECD. Notes for the UK data are for 2007 not 2008.

and just under 200,000 in the second. Controls include gender, age, education, whether these are recession years (2009-2012) and whether the respondent is from the Accession countries or some other nationality other than Greek. The recession brought higher unemployment. The most educated have the lowest probability of being unemployed or long-term unemployed, as expected. We also find foreigners have lower probabilities of both being unemployed and longer durations. As noted earlier, females have higher probabilities of both being unemployed and long durations. Once characteristics are controlled for, the age group 25-29 has a lower probability of both LTU and unemployment than either 20 to 24-year-olds or 15 to 19-year-olds.

We have seen that there is a huge amount of unemployment in Greece, but there is a high level of underemployment, as noted above. Figure 10 shows that young workers in Greece were hit by a double whammy; they couldn't find jobs, but when they could, the jobs would see reductions in hours from 2005-2012 that were especially marked. 


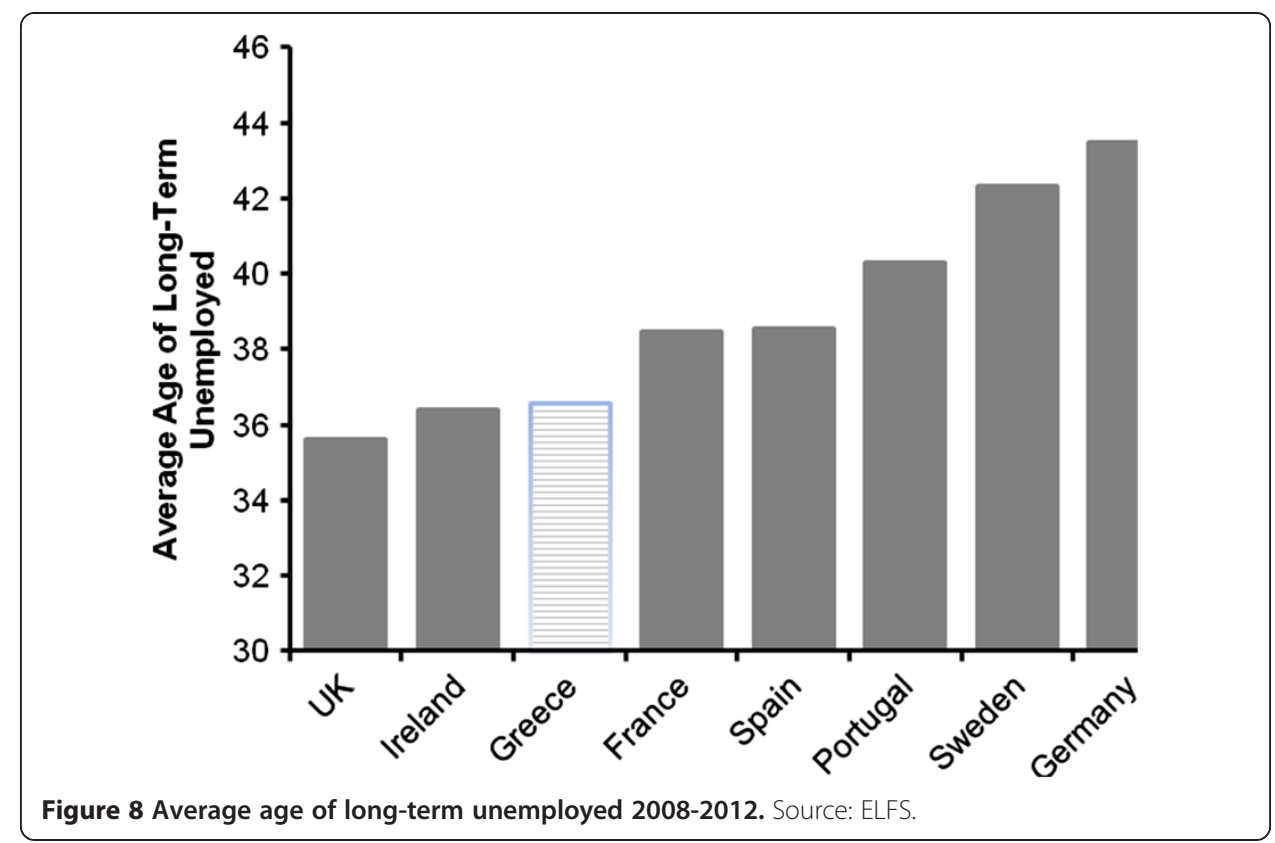

Figure 11 shows that they desired more hours than they are working and hence are underutilized. This suggests there is a large amount of slack in the Greek labour market both from the unemployed and from the employed who would like to work more hours.

\section{The well-being of Greek youth}

How has the well-being of the young in Greece been affected by recession? Are the effects different from previous recessions since the probability of finding a job match is now much lower, i.e., hopelessness? For earlier work on happiness and well-being see Blanchflower (2009) and Blanchflower and Oswald (2004).

In Table 10, we report on well-being by country since 2000 using data from the Eurobarometer survey series conducted for the EU Commission. We report responses to a life satisfaction question asked in many but not all surveys. The specific question

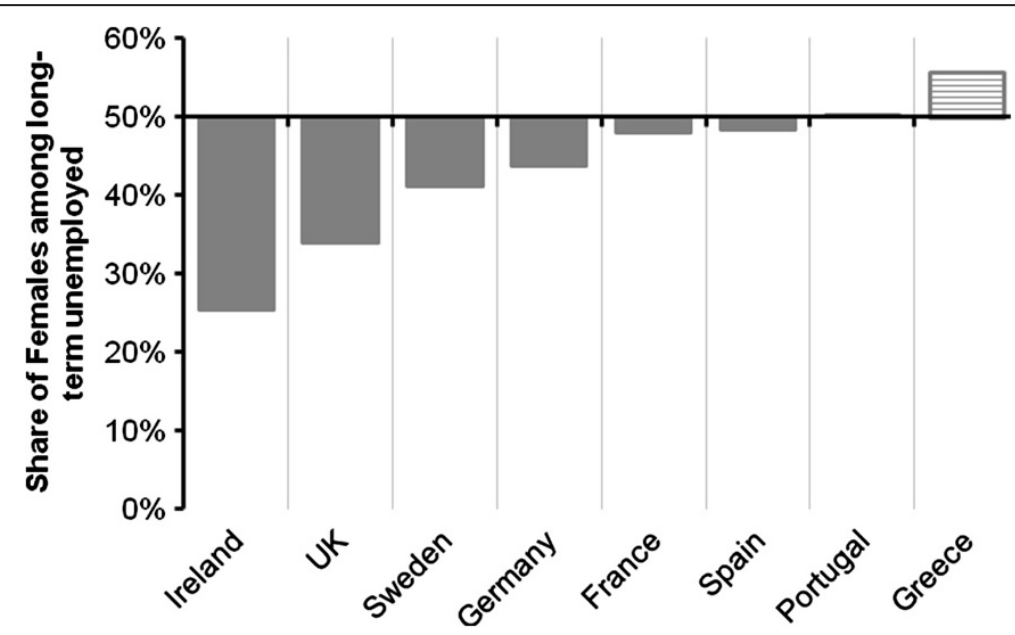

Figure 9 Proportion of females among long-term unemployed. Source: ELFS. 


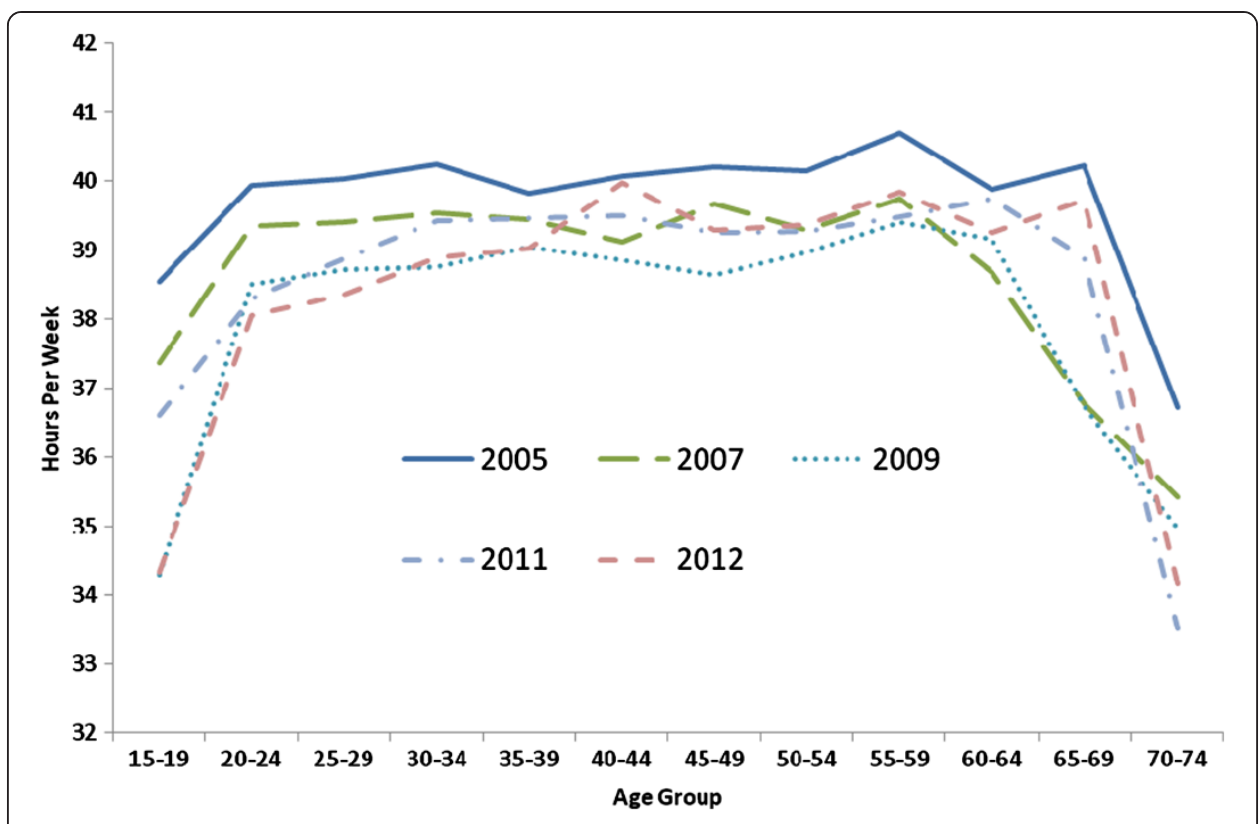

Figure 10 Actual weekly hours by age group 2005-2012, Greece. Source: ELFS.

used is as follows, "On the whole, are you very satisfied, fairly satisfied, not very satisfied or not at all satisfied with the life you lead?" We code the answers as 4=very satisfied, 3 = fairly satisfied, $2=$ not very satisfied and $1=$ not at all satisfied. These data have previously been used in Blanchflower et al. (2014) and Blanchflower (2009). Sample sizes are approximately 1000 per country per year. We report results for the average of the years of 2000-2007 (pre-recession) and 2008-2012 (post-recession) to ensure adequate sample sizes. We report overall results for the country as a whole and then separately for three age groups 15-24, 25-29 and 30+.

The main results are as follows:

- The happiest countries both pre- and post-recession are from Northern Europe. In order the happiest countries pre-recession were Denmark (3.60), Netherlands (3.37) and Sweden (3.36). Post-recession, the happiest were Denmark (3.65), Netherlands (3.46) and Sweden (3.46)

- There is evidence that the happiest countries saw increases in their happiness levels over the two time periods, especially in Denmark, Finland and the Netherlands.

- The least happy countries in the pre-recession period were from Eastern Europe Bulgaria (2.06), Romania (2.44) and Hungary (2.37).

- Over the two periods, Greece and Portugal ( -0.32 pts and -0.22 pts, respectively) followed by Italy and Spain ( -0.17 pts and -0.16 pts, respectively) had the most marked declines in happiness. It is notable that the happiness levels of the Irish remained unchanged.

- Consistent with Blanchflower and Oswald (2008), who found that happiness was U-shaped in age, the young are especially happy. In terms of the happiness levels of the youngest age group (15-24), the least happy and most happy countries were broadly the same as overall. 
Table 9 Probability of unemployment and long-term unemployment in Greece

\begin{tabular}{|c|c|c|c|c|c|c|c|c|}
\hline \multirow[b]{3}{*}{ Coefficient } & \multicolumn{4}{|c|}{ Aged 16-64 } & \multicolumn{4}{|c|}{ Aged 16-29 } \\
\hline & \multicolumn{2}{|c|}{$\begin{array}{c}\text { Long-term } \\
\text { unemployment }\end{array}$} & \multicolumn{2}{|c|}{ Unemployment } & \multicolumn{2}{|c|}{$\begin{array}{c}\text { Long-term } \\
\text { unemployment }\end{array}$} & \multicolumn{2}{|c|}{ Unemployment } \\
\hline & $d f / d X$ & $p$ value & $d f / d X$ & $p$ value & $d f / d X$ & $p$ value & $d f / d X$ & $p$ value \\
\hline Age $20-24$ & 0.092 & 0 & 0.150 & 0 & 0.009 & 0.005 & -0.073 & 0.000 \\
\hline Age 25-29 & 0.063 & 0 & 0.066 & 0 & -0.020 & 0.000 & -0.191 & 0.000 \\
\hline Age 30-34 & 0.031 & 0 & 0.013 & 0 & & & & \\
\hline Age 35-39 & 0.018 & 0 & -0.011 & 0 & & & & \\
\hline Age 40-44 & 0.007 & 0 & -0.029 & 0 & & & & \\
\hline Age 45-49 & -0.002 & 0.14 & -0.040 & 0 & & & & \\
\hline Age 50-54 & -0.003 & 0.034 & -0.043 & 0 & & & & \\
\hline Age 55-59 & -0.009 & 0 & -0.053 & 0 & & & & \\
\hline Age 60-64 & -0.020 & 0 & -0.072 & 0 & & & & \\
\hline Recession & 0.031 & 0 & 0.066 & 0 & 0.055 & 0.000 & 0.120 & 0.000 \\
\hline ISCED 1 & 0.004 & 0 & 0.008 & 0 & -0.003 & 0.344 & -0.008 & 0.077 \\
\hline ISCED 2 & 0.000 & 0.804 & 0.003 & 0.123 & 0.013 & 0.002 & 0.038 & 0.000 \\
\hline ISCED 3 & -0.001 & 0.042 & -0.003 & 0 & -0.008 & 0.002 & 0.004 & 0.272 \\
\hline ISCED 4 & -0.001 & 0.107 & 0.001 & 0.3 & -0.011 & 0.001 & 0.028 & 0.000 \\
\hline ISCED 5 & -0.023 & 0 & -0.037 & 0 & -0.020 & 0.000 & 0.032 & 0.000 \\
\hline ISCED 6 & -0.027 & 0 & -0.055 & 0 & -0.043 & 0.029 & -0.069 & 0.022 \\
\hline Other EU & -0.024 & 0 & -0.016 & 0 & -0.061 & 0.000 & -0.064 & 0.000 \\
\hline Accession States & -0.013 & 0 & 0.009 & 0 & -0.043 & 0.000 & -0.051 & 0.000 \\
\hline Other nationality & -0.012 & 0 & -0.003 & 0.275 & -0.038 & 0.000 & -0.042 & 0.000 \\
\hline Female & 0.044 & 0 & 0.068 & 0 & 0.073 & 0.000 & 0.111 & 0.000 \\
\hline$n=$ & 993578 & & 993578 & & 188286 & & 188286 & \\
\hline Pseudo R2 = & 0.066 & & 0.082 & & 0.038 & & 0.055 & \\
\hline obs. P & 0.059 & & 0.116 & & 0.109 & & 0.235 & \\
\hline pred P & 0.048 & & 0.098 & & 0.101 & & 0.222 & \\
\hline
\end{tabular}

Notes. In column 1, the dependent variable is 1 if unemployed for at least a year and zero if employed or unemployed for less than a year. In column 2, the dependent variable is 1 if unemployed and zero if employed. Columns 3 and 4 follow the same rules, respectively, but the dataset is restricted to those aged 16-29. ISCED (International Standard Classification of Education) levels broadly correspond to: $0=$ Pre-primary education; 1 = Primary education or first stage of basic education; $2=$ Lower secondary education or second stage of basic education; 3 = Upper secondary education; 4 = Post-secondary non-tertiary education; $5=$ First stage of tertiary education and $6=$ Second stage of tertiary education. So a higher ISCED number implies more education.

Omitted categories - Age 15-19, ISCED 0, Greek.

- Happiness levels of the 15-24 age group fell most in Portugal (-0.27 pts), Spain $(-0.21 \mathrm{pts})$ and Greece $(-0.21 \mathrm{pts})$. The countries hit hardest by high youth unemployment (also often associated with tight monetary and fiscal policies) in the Eurozone have experienced the biggest declines in their well-being. On any measure, this is bad.

- Of particular note is the especially sharp fall in happiness for those aged 25-29 in Greece (-0.29 pts), Spain (-0.21 pts) and Portugal (-0.22 pts). So in Greece the older of the two young cohorts experienced a bigger drop in happiness than the youngest cohort.

- Overall happiness fell more across all age groups in Greece (-.32) than in any other country. 


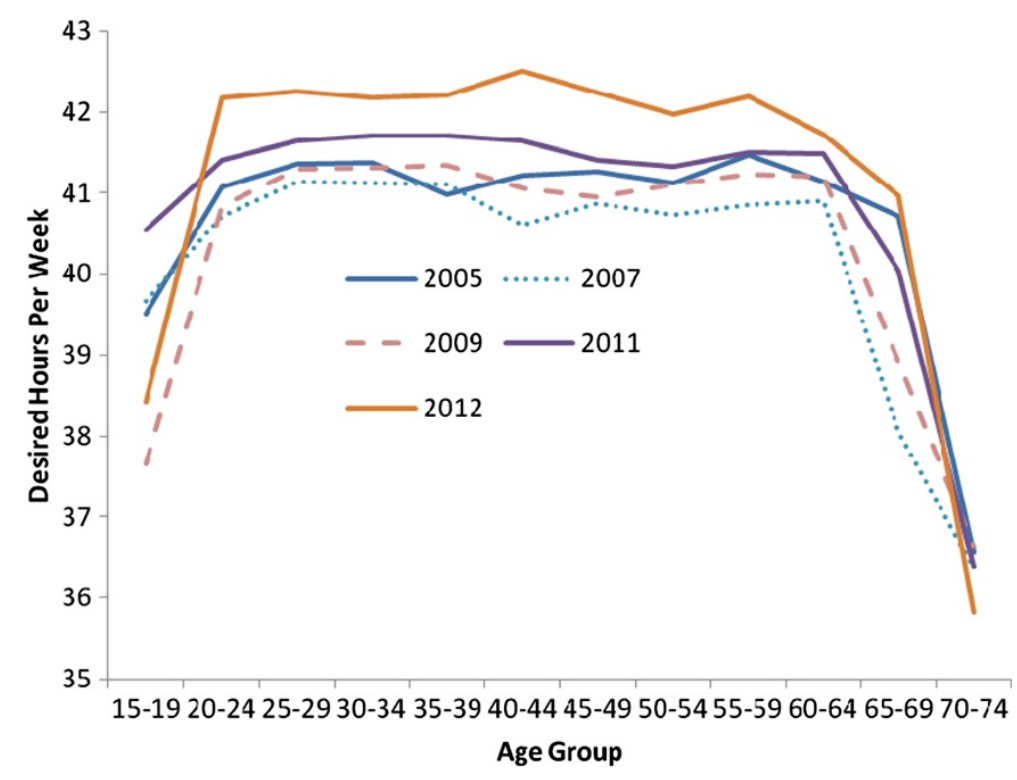

Figure 11 Desired weekly hours by age group 2005-2012, Greece. Source: ELFS.

Table 10 Well-being score by country and age group 2000-2007 and 2008-2012

\begin{tabular}{|c|c|c|c|c|c|c|c|c|c|c|c|c|}
\hline & \multicolumn{4}{|c|}{$2000-2007$} & \multicolumn{4}{|c|}{ 2008-2012 } & \multirow{2}{*}{\multicolumn{4}{|c|}{$\frac{\text { Changes } 2000-2007 \text { to } 2008-2012}{\text { Age group }}$}} \\
\hline & \multicolumn{4}{|c|}{ Age group } & \multicolumn{4}{|c|}{ Age group } & & & & \\
\hline & $15-24$ & $25-29$ & $30+$ & All & $15-24$ & $25-29$ & $30+$ & All & $15-24$ & $25-29$ & $30+$ & All \\
\hline Austria & 3.16 & 3.11 & 3.08 & 3.10 & 3.16 & 3.08 & 3.01 & 3.03 & 0 & -0.03 & -0.07 & -0.07 \\
\hline Belgium & 3.12 & 3.09 & 3.08 & 3.09 & 3.29 & 3.17 & 3.15 & 3.17 & 0.17 & 0.08 & 0.07 & 0.08 \\
\hline Bulgaria & 2.43 & 2.21 & 1.99 & 2.06 & 2.62 & 2.43 & 2.15 & 2.22 & 0.19 & 0.22 & 0.16 & 0.16 \\
\hline Denmark & 3.61 & 3.61 & 3.6 & 3.60 & 3.65 & 3.63 & 3.65 & 3.65 & 0.04 & 0.02 & 0.05 & 0.05 \\
\hline Finland & 3.24 & 3.24 & 3.15 & 3.17 & 3.39 & 3.38 & 3.27 & 3.29 & 0.15 & 0.14 & 0.12 & 0.12 \\
\hline France & 3.02 & 3.00 & 2.90 & 2.93 & 3.14 & 2.97 & 2.92 & 2.95 & 0.12 & -0.03 & 0.02 & 0.02 \\
\hline Germany & 2.90 & 2.89 & 2.90 & 2.90 & 3.1 & 3.00 & 3.01 & 3.02 & 0.2 & 0.11 & 0.11 & 0.12 \\
\hline Greece & 2.89 & 2.8 & 2.59 & 2.66 & 2.68 & 2.51 & 2.27 & 2.34 & -0.21 & -0.29 & -0.32 & -0.32 \\
\hline Hungary & 2.74 & 2.65 & 2.39 & 2.44 & 2.64 & 2.49 & 2.32 & 2.36 & -0.1 & -0.16 & -0.07 & -0.08 \\
\hline Ireland & 3.25 & 3.21 & 3.25 & 3.24 & 3.23 & 3.15 & 3.24 & 3.23 & -0.02 & -0.06 & -0.01 & -0.01 \\
\hline Italy & 2.96 & 2.91 & 2.84 & 2.87 & 2.83 & 2.75 & 2.69 & 2.7 & -0.13 & -0.16 & -0.15 & -0.17 \\
\hline Luxembourg & 3.29 & 3.3 & 3.34 & 3.33 & 3.35 & 3.28 & 3.38 & 3.37 & 0.06 & -0.02 & 0.04 & 0.04 \\
\hline Netherlands & 3.4 & 3.39 & 3.37 & 3.37 & 3.55 & 3.53 & 3.45 & 3.46 & 0.15 & 0.14 & 0.08 & 0.09 \\
\hline Poland & 3.12 & 3.0 & 2.70 & 2.79 & 3.09 & 3.02 & 2.78 & 2.83 & -0.03 & 0.02 & 0.08 & 0.04 \\
\hline Portugal & 2.87 & 2.77 & 2.50 & 2.58 & 2.6 & 2.55 & 2.3 & 2.36 & -0.27 & -0.22 & -0.2 & -0.22 \\
\hline Romania & 2.68 & 2.58 & 2.29 & 2.37 & 2.68 & 2.47 & 2.26 & 2.34 & 0 & -0.11 & -0.03 & -0.03 \\
\hline Slovakia & 2.84 & 2.81 & 2.60 & 2.64 & 3.03 & 2.91 & 2.73 & 2.77 & 0.19 & 0.1 & 0.13 & 0.13 \\
\hline Spain & 3.15 & 3.09 & 3.01 & 3.04 & 3.07 & 2.88 & 2.85 & 2.88 & -0.08 & -0.21 & -0.16 & -0.16 \\
\hline Sweden & 3.36 & 3.37 & 3.36 & 3.36 & 3.52 & 3.42 & 3.45 & 3.46 & 0.16 & 0.05 & 0.09 & 0.1 \\
\hline UK & 3.19 & 3.16 & 3.2 & 3.19 & 3.33 & 3.22 & 3.26 & 3.26 & 0.14 & 0.06 & 0.06 & 0.07 \\
\hline
\end{tabular}

Source: Eurobarometer Surveys, 2000-2012. 


\section{Conclusion}

There is little evidence from the literature that ALMPs work, especially in a recession where over a quarter of the labour force and over a half of the youth labour force are unemployed. This is unprecedented territory when overall unemployment is so high and an immediate expansion in aggregate demand is precluded.

The age group 25-29 in Greece is probably of greatest concern because numerically their unemployment is much larger than those aged 15-19. The share of this group who are NEETS is worryingly high. This group is excluded from the usual understanding of youth unemployment, but they were the ones who were young when the recession first hit. Hence, many were unable to make the transition from school to work. There is an issue as to whether this group is experiencing age or cohort effects. Clearly this is an important distinction in relation to the scarring effects of unemployment on this group.

The conventional ratio of youth to adult unemployment is not particularly high in Greece, partly due to the effects of 25-29 year olds. This begs the question of whether it is overall lack of demand that is the problem or if there are specific issues in the Greek youth labour market. Youth unemployment was relatively high prior to the recession - in fact, the youth/adult unemployment rate ratio in Greece has been trending downwards - unlike most other countries. In addition, student (part-time) employment and unemployment is rare in Greece and much less important than in, say, the UK. They do not significantly affect age-specific unemployment rates.

The European Labour Force Survey indicates that numbers in Greece in the 15-29 age group is falling. This is a combination of the effects of declining cohort size and increased emigration, which seems to have been particularly marked among women ages 25-29.

There are very significant differences in labour market outcomes for males and females in Greece. Female activity rates and employment to population ratios are consistently lower and unemployment rates higher for females than for males in the Greek labour market. Gender differentials in Greece are more marked than in many other EU states.

Greek youths are much more likely to live at home than are young people in Northern Europe. A similar pattern is found in Spain and Portugal. This mitigates the costs of unemployment, but may also restrict mobility, leading to longer unemployment durations. Again, there are significant gender differentials, with females aged 25-29 more likely to have moved away from the parental home than males. NEET women are more likely to live away, while NEET men are more likely to live at home than are the employed of the same gender. The Great Recession was associated with fairly minor changes in these probabilities. So there has not been a big "return to Mum" in response to recent economic events, other than for females ages 25-29 in Greece, with the proportion living alone dropping from $53 \%$ in 2005 to $43 \%$ in 2012.

There is evidence also that many young workers are underemployed and are in parttime jobs when they would like to have full-time and in temporary jobs when they would like permanent ones. Among European countries, Greece has the highest proportions of the young unemployed that have been without work for more than a year. So scarring effects are likely to be large, especially for those 25-29 who were hit hardest by the 2008 recession shock and failed to make a successful transition from school to work. An extremely high proportion of these young adults continue to live with their parents.

The decline in Greek well-being since the beginning of the recession has been the most rapid in Europe. However, it is evenly spread across age groups and not 
specifically focused on the young. Lack of mobility due to rigidities in the housing market seems to be a major issue in Greece. Worryingly, we see no evidence that these extremely high rates of youth unemployment in Greece are going away any time soon.

\section{Endnotes}

${ }^{1}$ http://epp.eurostat.ec.europa.eu/cache/ITY_PUBLIC/3-28022014-AP/EN/3-28022014AP-EN.PDF

${ }^{2}$ Sweden is not included because all relevant data were not available.

${ }^{3}$ Bell and Blanchflower (2011a) find that young workers want more hours, while older workers want less hours.

\section{Competing interests}

The IZA Journal of European Labor Studies is committed to the IZA Guiding Principles of Research Integrity. The authors declare that they have observed these principles.

\section{Acknowledgement}

Paper presented at the Stavros Niarchos Foundation conference: Recharging the Youth: an international conference on the global youth unemployment crisis and the need for collective action. The authors would like to thank the anonymous referee.

Responsible editor: Martin Kahanec

\section{Author details}

'Division of Economics, Stirling Management School, University of Stirling, Stirling, UK. ²Department of Economics, Dartmouth College, USA. ${ }^{3}$ Peterson Institute for International Economics, UK.

Received: 25 June 2014 Accepted: 12 September 2014

Published: 29 Jan 2015

\section{References}

Auspos P, Riccio J, White M (1999) A review of US and European literature on the microeconomic effects of labor market programmes for young people, Employment Service, Research and Development Report no 20, July 1999. The Employment Service, Sheffield

Bell DNF, Blanchflower DG (2011a) UK underemployment in the Great Recession. Nat Inst Econ Rev 215:R23-33

Bell DNF, Blanchflower DG (201 1b) Youth unemployment in Europe and the United States'. Nord Econ Pol Rev number 1:11-38 Bergemann A, van den Berg GJ (2006) Active Labor Market Policy effects for women in Europe: a survey. IZA Discussion Paper 2365 Blanchflower DG (2009) International evidence on well-being. In: AIB K (ed) Measuring the Subjective Well-Being of Nations: National Accounts of Time Use and Well-Being. NBER and University of Chicago Press

Blanchflower DG, Oswald AJ (2004) Well-being over time in Britain and the USA. J Public Econ 88:1359-1386 Blanchflower DG, Oswald AJ (2008) Is well-being U-shaped over the life cycle?'. Soc Sci Med 66(6):1733-1749 Blanchflower D, Bell D, Montagnoli A, Miro M (2014) Journal of Money, Credit and Banking, 46(S2):117-141 Calmfors L, Forslund A, Hemström M (2002) Does Active Labor Market Policy work? Lessons from the Swedish Experiences. Institute for International Economic Studies, Stockholm University

Card D, Kluve J, Weber A (2009) Active labor market policy evaluations: a meta-analysis. Econ J 120:F452-F477 Cholezas I (2013) Youth guarantee in times of austerity: the Greek case. Friedrich Ebert Stiftung, discussion paper Grubb WN (1999) Lessons from education and training for youth: five precepts, in preparing youth for the 21st Century: the transition from education to the labor market'. OECD, Paris

Heckman JJ, Smith JA (1999a) The pre-programme earnings dip and the determinants of participation in a social programme. Implications for simple evaluation strategies. Econ J 109:313-348

Heckman JJ, Smith JA (1999b) The sensitivity of experimental impact estimates: evidence from the National JTPA Study'. In: Blanchflower DG, Freeman RB (eds) Youth employment and joblessness in advanced countries. University of Chicago Press and NBER, Chicago

Kahn LB (2010) The long-term labor market consequences of graduating from college in a bad economy'. Labour Econ 17(2):303-316

Kluve J (2010) The effectiveness of European active labor market programs. Labour Economics 17(6):904-918 Martin JP, Grubb D (2001) What Works and for Whom: A Review of OECD Countries' experiences with active labour market policies (No. 2001: 14), Working Paper, IFAU-Institute for Labour Market Policy Evaluation

OECD (1994) The OECD Jobs Study: Facts, Analysis, Strategies. OECD, Paris

Pastore F (2012) Youth unemployment in Italy at the time of the new great depression'. Friedrich Ebert Stiftung, discussion paper Pastore (2013) The European Youth Guarantee: an Italian perspective". Soc Eur J, www.social-europe.eu, 23.5.2013 Rocha Sánchez F (2012) Youth unemployment in Spain. Friedrich Ebert Stiftung, discussion paperik

Tubadji A (2012) Youth unemployment in Greece: economic and political perspectives'. Friedrich Ebert Stiftung, discussion paper

10.1186/2193-9012-4-1

Cite this article as: Bell and Blanchflower: Youth unemployment in Greece: measuring the challenge. IZA Journal of European Labor Studies 2015, 4:1 